\title{
Patenting Genetic Material in Aquaculture: A Red Herring or an Emerging Issue to Tackle?
}

\section{Fran Humphries*}

Griffith Law School, Australian Centre for Intellectual Property in Agriculture, Griffith University, Australia

\begin{abstract}
Patents can have both a positive and negative effect on innovation in aquaculture. On the one hand they may encourage investment in aquatic biotechnology. On the other hand, they may tie up genetic resources and research tools that may have otherwise been freely used by breeders or researchers to develop new breeds. This article considers the role and use of patent law for protecting new strains in aquaculture from unauthorised replication. While patents are not yet as extensive in aquaculture compared with other fields, there are issues that need to be addressed from the outset to protect aquaculture's increasing role in global food security. Depending on the laws in a particular jurisdiction, patents could be claimed over genetic material products, including those derived from conventional breeding, as well as over processes for example methods of gene research. A central problem for breeders is determining the extent to which a patent holder can control other people's use of subsequent generations whose breeding line originally incorporated the patented invention. In addressing this problem, the article suggests that exceptions against infringement including experimental use exceptions may be a useful avenue for breeders. It also highlights breeding defences and innocent bystander defences that are emerging in agriculture but which may also have future relevance to aquaculture. The article concludes that as patents start to take hold in aquaculture, breeders need clarity on the circumstances in which they can make a cross with an aquatic strain that includes patented genetic materials (such as a sequence or trait) that are not expressed in their new strain.
\end{abstract}

Keywords: Patent law; Aquaculture; Patenting genetic material; Patent exceptions for breeding

\section{Introduction}

Aquaculture farmers and breeders need legal certainty about how the increasing number of patents over aquatic genetic material can affect their breeding programs. While aquaculture is still in its early stages of development as an industry, an important question to resolve is how patents can be used to promote innovation by financially rewarding investment, while still making available breeding material to develop new strains that can be adapted to changing environmental and market conditions. This article looks at whether patent law is set to become an increasing influence on breeding in aquaculture, and if so, what are some emerging problems that need to be tackled to enable the breeding of new strains to meet global demands for fish.

\section{Options for Protecting 'Improved' Genetic Material}

Patents are just one of a range of options available to breeders and researchers to protect their investment and effort in experimenting with breeding new strains of fish by limiting the availability of their 'improved' genetic material for use by others. More common options include:

- $\quad$ Trade secrets (where the holder makes reasonable efforts to keep the information from the public);

- Sex manipulation (eg where sex-reversed females are crossed with normal females to produce all female stock such as with Tasmanian Atlantic salmon [1]);

- Inducing sterility (eg through polyploidy where reproduction is incompatible between individuals such as with shrimp [2]);

- Vertical integration (where the production of fish seed, grow out, preparation of feeds, post-harvest processing and marketing are controlled by the one operation [3]); and

- Market concentration (where a small number of companies control the market for a particular species such as in the salmon industry [4]).

Patents are becoming a more viable option for protecting 'improved' genetic material. Thirty years ago, one of the first cases in the US finding that animals could be patented concerned a polyploid oyster [5].

\section{Extent of Patents in Aquaculture}

Two of the reasons why the number of patents in aquaculture is not yet as extensive as in agriculture include aquaculture's relatively undeveloped industry status and its reliance on wild stocks. Industrial aquaculture was virtually unknown 40 years ago but is now emerging as the fastest growing global food production sector, accounting for almost half of the food fish consumed by humans [6]. Developing countries provide about 80 per cent of global aquaculture production [7]. These countries generally have weaker patent laws than developed countries which may discourage investment in patents in developing countries. Further, most small farmers cannot afford or have no practical use for patents.

Aquaculture overwhelmingly relies on wild stocks for current breeding (90 per cent) [8] which are not human-made inventions and are therefore, not patentable in principle. Of the remaining ten

*Corresponding author: Fran Humphries, Griffith Law School, Australian Centre for Intellectual Property in Agriculture, Griffith University, Australia, Tel: (07) 3735 5339; E-mail: frances.humphries@griffithuni.edu.au

Received July 21, 2015; Accepted October 28, 2015; Published January 15, 2016

Citation: Humphries F (2015) Patenting Genetic Material in Aquaculture: A Red Herring or an Emerging Issue to Tackle? J Aquac Res Development 6: 394. doi:10.4172/2155-9546.1000394

Copyright: (c) 2015 Humphries F. This is an open-access article distributed under the terms of the Creative Commons Attribution License, which permits unrestricted use, distribution, and reproduction in any medium, provided the original author and source are credited. 
per cent of aquatic stocks that are genetically improved and capable of being patented, most of these are derived from selective breeding programmes rather than biotechnology [8]. Currently, no patented genetically engineered aquatic species have been approved for commercial production [9] but there are some decisions pending. For example, AquaBounty Technologies is seeking permission from the United States Food and Drug Administration (FDA) to commercialise its patented transgenic AquAdvantage Salmon [10]. Aquatic biotechnology particularly in relation to DNA markers and transgenics [11] is expected to rapidly increase over the coming years to meet the expected global demands for animal protein.

Some of the reasons why patents are likely to become an increasingly important option to protect investment in breeding and research is because of the high cost of investment for biotechnology related inventions, the expense and risk of developing fast-growing diseasefree fish [12] and the increasing concentration of big companies in aquaculture that can afford to claim and defend patents [7].

\section{How do Patents Work?}

Patent laws are national in operation. In reality, many countries' patent laws are constrained by international law if they are members of the World Trade Organisation (WTO). The Agreement on Trade Related Aspects of Intellectual Property Rights (TRIPS) provides an international framework for national patent laws of WTO Members [13]. As a minimum level of protection, all Members must, subject to options for exclusion (explained below), make exclusive rights available for any invention in any field of technology provided the product or process is new, non-obvious and capable of industrial application [14].

Australia has implemented these requirements under s. 18 Patents Act 1990 (Cth). A standard patentable invention must be:

- $\quad$ Novel

o Not known to the public before the date of filing an application;

- Involve an inventive step

o Not obvious to a person skilled in the relevant art;

- Useful

o Having a specific, substantial and credible (not hypothetical) use; and

- A 'manner of manufacture' within the meaning of s. 6 of the UK's Statute of Monopolies

o Generally meaning that a patent must relate to the applied arts rather than fine arts and must involve some sort of human intervention.

A patent system attempts to provide a balance between encouraging innovation by rewarding the first-comer who creates an invention on the one hand, with preserving sufficient knowledge for the public to produce additional inventions on the other. Patent holders have exclusive rights over the making, use, sale, offering for sale and importing of the products of an invention [14]. In the case of a process, the rights extend to preventing a person from unauthorised use of the process and from using, offering for sale, selling and importing at least the product directly obtained from the process [14]. In exchange for these exclusive rights, the patentee must disclose certain information to the public domain so that someone skilled in that area can carry out the invention independently [14].

\section{Patents and Aquatic Genetic Material}

Potential claims for patents of relevance to aquaculture can include product claims as well as process claims.

Product claims can be made over:

- Actual genetic materials:

o Including DNA, RNA, genes, chromosomes and gene fragments such as single nucleotide polymorphisms, expressed sequence tags and other gene fragments encoding important regions of proteins;

- As well as genetic products that are produced by the use of genetic materials;

o Including chemical compounds, nucleic acid probes, nucleic acid constructs such as vectors and plasmids, and anti-sense DNA [15].

Process claims on the other hand, can include methods of gene research, promoters, transformation processes, the use of virus coat proteins to confer resistance and antisense technology [16].

An important issue for breeders is whether conventional breeding processes and the products derived from conventional breeding can be patented. Basically, this comes down to how a nation has implemented its TRIPS obligations.

Under the TRIPS agreement, WTO Members have the option of excluding plants and animals from patentability, but members must allow the patenting of micro-organisms [17]. The boundaries, however, between plants, animals and microorganisms remains disputed [18]. If a patent law extends protection to all material in which the product is incorporated [19], then a broad patent claim over the gene or gene carrier (vector) of a plant or animal may have the same outcome as patenting the whole plant or animal [20]. The holder of a patented strain may then be able to prevent others from using it for breeding purposes.

WTO Members also have the option to exclude from patentability essentially biological processes (in other words, conventional breeding) for the production of plants or animals but they must allow the patenting of non-biological and microbiological processes [17]. The European Patent Convention does not allow patents over essentially biological processes [21]. Significantly, a recent EU decision relating to broccoli and tomato found that the plants produced according to an essentially biological process are, however, patentable in principle [22]. While the decision related to plants, the principle is likely to be similarly interpreted for animals in future. This means that breeders may not make use of relevant breeding processes since this would inevitably lead to patented products [23].

\section{Effect of Patents on Breeding}

While patents can promote innovation by rewarding investment in biotechnology and breeding on the one hand, the far-reaching effects of a patent claim can pose obstacles for innovation to develop new strains. Biotechnology research is particularly susceptible to patent thickets that can dampen innovation [24]. For example, experimenting on one transgenic aquatic animal may require authorisation from a range of patent holders for different traits such as promoters and terminator sequences [25]. This might mean that experimentation is cost prohibitive or impractical. 
A breeder would need to pay a patent holder for a licence to breed with genetic material or a process claimed under a patent. Breeders face problems when a licence is cost prohibitive or refused so that the genetic material is not available for breeding new strains. Many farmers or breeders may not even be aware that their breeding material incorporates material that was patented in previous fish generations. Breeders are susceptible to infringement proceedings arising from intentional or accidental incorporation of patented genetic trait when cross breeding, even if they do not intend to use the patented trait or process.

\section{Challenges for Breeders}

These effects pose a major challenge for aquaculture breeders and researchers. As a generalisation, protection under patent law extends to every plant or animal containing the inventive element or resulting from a patented process [26]. A key question is, how far does a patent holder's control extend to subsequent generations whose breeding line originally incorporated a patented product or process? In other words what is the extent to which a new strain may contain a patented trait without being liable for infringement? For example, would a user be liable for infringement if an anti-freeze gene promoter expressed in an initial patented transgenic fish is present, but not expressed or 'switched on' in subsequent fish strains that are the result of a cross between the transgenic fish and another strain incorporating different genetic combinations [27]?

There is some guidance from European courts that a patented trait may be present in material derived from the invention, but patent protection may only attract when the patented trait is performing its function at the time of the alleged infringement [28]. This means that there may not be infringement if the patented trait is merely present ie not expressed in a subsequent fish strain at the time it is being used [27]. But there is still legal uncertainty in this area and many countries have not had decisions to clarify the reach of a patent holders' control in new strains.

\section{Options for Sharing Genetic Material for Breeding and Experimentation}

While exclusions from patentability can be undermined by clever claim drafting, a nation may include exceptions for infringement in their patent laws. A widespread exception is the experimental use exception which may allow experimental uses on the invention for example for the purpose of improving, further developing and testing a patented genetic material invention [29].

Other exceptions or defences against infringement that are emerging in agriculture but may evolve to encompass breeding in aquaculture include breeding defences and innocent bystander defences. Breeding defences may allow the use of biological material for breeding, discovery and development of a new strain but not commercialisation of a new strain that incorporates a patented product [30]. Innocent bystander defences may allow the use of patented genetic material where the genetic information was bred into new strains without the breeder's knowledge or against their will [31]. These sorts of exceptions in national laws are rare but may be crucial in getting the balance right between rewarding investment in research by granting patents and encouraging the breeding of new strains in circumstances where authorisation from the patent holder is impractical or impossible.

\section{Conclusion}

To fully understand the impact of patent law on breeding in aquaculture and to ensure that breeders can make use of exceptions for infringement, the law needs clarity on the extent to which breeders can make subsequent crosses with an aquatic strain that includes a patented genetic trait but which is not expressed in their new strain. If accessing genetic material for breeding in aquaculture follows the same trends as in agriculture, there is a global urgency to address these sorts of legal questions as patents increasingly start to take hold.

\section{Acknowledgements}

I am grateful for the comments I received on this paper from Charles Lawson, Griffith University Australia.

\section{References}

1. Eisbrenner WD, Botwright N, Cook M, Davidson EA, Dominik S, et al. (2014) Evidence for multiple sex-determining loci in Tasmanian Atlantic salmon (Salmo salar). Heredity 113: 86-92.

2. http://www.chnpat.com/CN31/201010044829.html

3. http://documents.worldbank.org/curated/en/2007/01/8822592/changing-facewaters-promise-challenge-sustainable-aquaculture.

4. Organisation for Economic Co-operation and Development (2010) Globalisation in fisheries and aquaculture: opportunities and challenges.

5. (1987) Federal Circuit, Although the application failed on the grounds of obviousness. Ex Parte Allen, 2 U.S.P.Q.2d 1475

6. Greer D, Harvey BJ (2004) Blue genes: sharing and conserving the world's aquatic biodiversity. Earth scan, London.

7. Bartley DM (2009) The use and exchange of aquatic genetic resources for food and agriculture. Background Study Paper No 45, FAO Commission on Genetic Resources for Food and Agriculture.

8. Gjedrem T (2012) Genetic improvement for the development of efficient global aquaculture: a personal opinion review. Aquaculture 344-349: 12-20.

9. Dunham RA (2011) Aquaculture and fisheries biotechnology and genetics. 2nd Edition. CABI Publishing,UK.

10. Sanderson J, Humphries F (2015) Unnaturally natural: inventing and eating genetically engineered AquAdvantage ${ }^{\circledR}$ salmon, and the paradox of nature. Intellectual property and genetically modified organisms: a convergence in laws. Ashgate Publishing.

11. Rosendal K, Olesen I, Tvedt MW (2013) Evolving legal regimes, marke structures and biology affecting access to and protection of aquaculture genetic resources. Aquaculture 402-403: 97-105.

12. Hayes B, Andersen $O$ (2005) Modern biotechnology and aquaculture. Selection and breeding programs in aquaculture, Springer, Netherlands.

13. (1994) Agreement on Trade-Related Aspects of Intellectual Property Rights, opened for signature, Marrakesh Agreement Establishing the World Trade Organisation, Annex 1C, 1869 UNTS 299.

14. TRIPS article 27(1), 28(a), 28(b), 29.

15. Blakeney M (2009) Biotechnological patenting and innovation. Patents and technological progress in a globalized world, Springer Berlin Heidelberg Germany.

16. Barton J (2004) Acquiring protection for improved germplasm and inbred lines Intellectual property rights in agricultural biotechnology. CAB International, NY USA.

\section{TRIPS article $27(3)$.}

18. Malbon J, Lawson C, Davison MJ The WTO Agreement on Trade-Related Aspects of Intellectual Property Rights: a commentary. Edward Elgar Publishers. USA.

19. http://eur-lex.europa.eu/legal-content/EN/TXT/?uri=CELEX:31998L0044

20. Nuffield Council on Bioethics (2004) The use of genetically modified crops in developing countries - a Follow up Discussion Paper

21. Article 53(b) (1973) Convention on the Grant of European Patents - (European Patent Convention). 
Citation: Humphries F (2015) Patenting Genetic Material in Aquaculture: A Red Herring or an Emerging Issue to Tackle? J Aquac Res Development 6: 394. doi:10.4172/2155-9546.1000394

Page 4 of 4

22. (2015) Decision of the Enlarged Board of Appeal, of 25 March, Case number G 0002/13.

23. Then C, Tippe R (2014) European patents on plants and animals - Is the patent industry taking control of our food?. Report published by No Patents on Seeds.

24. Mueller JM (2001) No "dilettante affair": rethinking the experimental use exception to patent infringement for biomedical research tools. Washington Law Review.

25. Correa CM (2012) TRIPS-related patent flexibilities and food security: options for developing countries. International Centre for Trade and Sustainable Development and Quaker UN Office, Policy Guide.

26. Prifti V (2013) The breeding exemption in patent law: analysis of compliance with Article 30 of the TRIPS Agreement. The Journal of World Intellectual Property 16: 218-239.

27. Humphries F (2015) Shellfish patents krill experimentation: Defences for sharing patented aquatic genetic materials in aquaculture. European Intellectual Property Review 37: 210-224.

28. Monsanto Technology LLC v Cefetra BV (C-428/08) [2010] E.C.R. I-6765; [2012] 3 C.M.L.R. 7 at [50].

29. Section 119C Patents Act 1990 (Cth) Australia.

30. German Patent law, section 11(2) (b).

31. Swiss Patent law, article 9(1)(f). 